\title{
ICT Usage of Concept Map as a Method of Memorizing and Making Notes
}

\author{
Md. Nazri Rahim, Muhammad Hussin, Normaulida Aniz Candra
}

To Link this Article: http://dx.doi.org/10.6007/IJARBSS/v11-i3/9030

DOI:10.6007/IJARBSS/v11-i3/9030

Received: 06 January 2021, Revised: 31 January 2021, Accepted: 23 February 2021

Published Online: 22 March 2021

In-Text Citation: (Rahim et al., 2021)

To Cite this Article: Rahim, M. N., Hussin, M., \& Candra, N. A. (2021). ICT Usage of Concept Map as a Method of Memorizing and Making Notes. International Journal of Academic Research in Business and Social Sciences, 11(3), 1009-1022.

Copyright: (c) 2021 The Author(s)

Published by Human Resource Management Academic Research Society (www.hrmars.com) This article is published under the Creative Commons Attribution (CC BY 4.0) license. Anyone may reproduce, distribute, translate and create derivative works of this article (for both commercial and non-commercial purposes), subject to full attribution to the original publication and authors. The full terms of this license may be seen at: http://creativecommons.org/licences/by/4.0/legalcode

Vol. 11, No. 3, 2021, Pg. 1009 - 1022

Full Terms \& Conditions of access and use can be found at http://hrmars.com/index.php/pages/detail/publication-ethics 


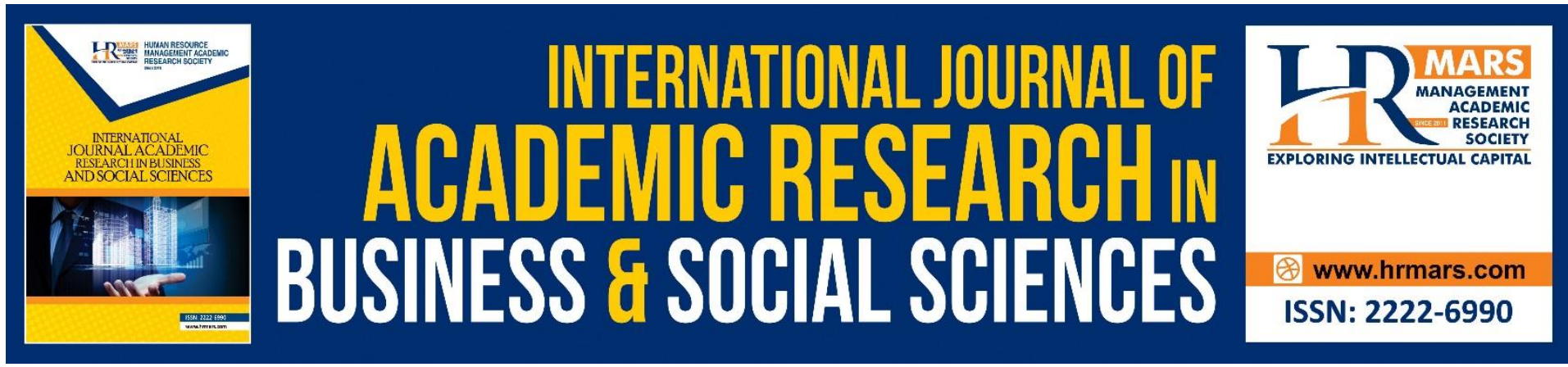

\title{
ICT Usage of Concept Map as a Method of Memorizing and Making Notes
}

\author{
Md. Nazri Rahim, Muhammad Hussin, Normaulida Aniz Candra \\ Faculty of Education, Universiti Kebangsaan Malaysia, 43600 Bangi, Malaysia \\ Email:koperasisiswazah@gmail.com,muhsin@ukm.edu.my,normaulida.anis@gmail.com
}

\begin{abstract}
This study aims to determine the effectiveness of the use of ICT-based concept mapping as a means for students to make notes and remember the concepts and facts of economic subjects. Computer based learning can produce smart learning environment that encourages students to think critically and creatively. Ten lower sixth form students from a school in Negeri Sembilan serve as respondents of this study. The questionnaire given to the students before and after completing the process of teaching using this method. Original findings before implementing this method showed $70 \%$ of students do not like to copy the notes in the form of linear and difficult to understand concepts and economic facts and implemented after the study found $80 \%$ of students believe the use of ICT-based mind maps can help students remember facts and concepts in a more systematic and organized and make a note of interest to use ICT-based concept map. Results of this study showed the use of ICT-based concept mapping has shown positive effects in enhancing recall concepts and facts, make a note of the interest for students to revise and enhance students' creativity.
\end{abstract}

Keywords: Concept Map, ICT, Making Notes, Economics, Action Research

\section{Introduction}

The use of concept maps that can be seen as to facilitate students' thinking, help strengthen memory, and enable students to remember important facts that can then be described well. Therefore, the use of concept maps as a teaching technique in Economics indirectly will make the learning process more effective and thereby improve student achievement in the subjects of Economics.

According to Tee et al (2009), the concept map is a sketch of a topic or theme in the middle and a few lines expanded to the surrounding to illustrate expanding ideas and the small branches of the topic. Concept map is very suitable to be used to make notes on a topic for a subject on the basis of usage. In line with the purpose of the concept map is that it allows students to take notes with a simple and easy way to remember as well as combining and balancing the use of the right brain and left brain during learning. Thus, the concept map is very suitable and accurate for the purposes of this study so that students can create, store and review the notes properly and effectively. 
Steven (2000) states that the use of concept maps is a simple cognitive strategy to apply. Students will learn the material that were taught quickly when teaching is made in the form of sketches using pictures or words in structured form. Students will also be able to use their intellectual skills to think for a way to solve a given problem based on the subject being taught. Students who are having difficulty will choose a simple way to select and understand the lesson content which represent the topic with the help of peers or teachers.

Concept map is a schematic summary of student knowledge (Novak \& Gowin, 1984). Concept maps can be used to highlight students' prior knowledge about a given topic, or to summarized something that was already learned. Concept maps can also be used as teaching aids or notes. Construction of the concept map is a creative activity for students to strive to explain the concept by identifying essential concepts and its relationships. This activity stimulates the response to the knowledge and understanding of the students (Novak \& Gowin, 1984).

Schaal (2008); Yeyiloglu et al (2008) used concept maps as assessment instruments in their study of the pre-test concept maps and post-test concept maps. Scores of both tests were analyzed using paired sample t-test. The analysis showed a significant difference between the pre-test mean score concept maps and post-test mean score concept maps. Mean increase in the post-test achievement concept maps. Based on these results, they concluded that the students knowledge have grown well after teaching using concept maps.

The economic subject is a literary subject at STPM (Malaysian Higher School Certificate) upper secondary school. Form six economics students often face difficulty in understanding abstract concepts. This problem is more apparent in the lower form six students who are new to the economic subject and they had difficulty in understanding the concepts, particularly those who do not have the basic of the economic subject in SPM. Researchers such as Hussin (1999) who did research on economic learning suggests that teachers perform well especially in economic lessons to new students that started learning economic subjects to develop critical thinking skills and a good and clear understanding of economic concepts.

Facts are related to concept due to fact is considered information or data in the process of thinking, then emphasis on teaching techniques that enable students to master the concepts of the economy subject is necessary by the teacher. Thus, the use of concept maps in teaching and learning of economics is considered a very appropriate teaching technique. This is because the use of concept maps help students to be more focused, and can make interpretation easier to understand the topics studied. This opinion is consistent with the view of Hussin (1999) on the use of concept maps that is seen to be able to ease students thinking, help strengthen memory, and to be able to remember important facts that can then be described well. Therefore, the use of concept maps as a teaching technique in the subject of economics indirectly will make the learning process more effective and thereby improve student achievement in this subject.

\section{Statement of the Problem}

"When I was marking papers for February and March Planned Tests in the subject of economy, I found that many students are not able to explain the concept and provide accurate facts and failed to properly explained it. Description of the fact that should have certain keywords in support of that fact cannot be described accurately provided by the students. From interviews I have conducted, the class students responded that they did not remember the facts they have learned in addition to elaborate fact that have a certain keyword. What is the easiest 
and interesting technique that can help these students understand the concepts and memorize facts and thus allowing students to answer essay questions well in addition becoming more interested in learning the economy subject. "

Based on the above problems, it is found that:

a) Students are not able to remember the basic concepts and facts of economic subject by title in the syllabus.

b) Students are not able to write exactly the basic concepts and facts of economic subjects while answering essay writing questions.

c) Students have no method remembering the basic concepts and facts of economic subjects in a planned and systematic manner.

d) Students still use the traditional method of making notes.

\section{Purpose of the Study}

The purpose of this study is to introduce the use of ICT based concept mapping as a method of remembering facts and concepts and provides techniques to make notes to request titles.

\section{Objectives of the Study}

Research objectives to be achieved for the students are:

a) To introduce a method of learning using ICT based concept mapping as a way to remember facts and concepts in economic subjects.

b) Increase the interest of students to remember concepts and economic facts using ICT based concept map.

c) Increase students' interest to make revision notes with the use of ICT based concept map.

\section{Research Questions}

Research questions to be studied are:

a) Does the use of ICT based concept mapping is an appropriate way to remember the concepts and facts of economy subjects systematically.

b) Does the use of ICT based concept maps can improve the interest of students to remember concepts and facts of economic subjects.

c) Is the use of ICT based concept maps can enhance the interest of students to make revision notes.

\section{Conceptual Framework of Research}

The design of this study is an action research exploring the use of ICT based concept maps to enhance the ability to remember concepts and facts of economic subjects by using quantitative and qualitative method to retrieve the data. According to McNiff et.al (2003), action research is an approach to fix or improve the quality of education through changes that encourage teachers to be more aware of their own practice, to be critical of such practices and are willing to change practices. Researchers have used the action research model based on the Carr and Kemmis (1986) model. This model outlines four phases: Phase 1 is the development of an action plan to improve the current situation, Phase 2 is acting according to the plan, Phase 3 is collecting and analyzing data and Phase 4 is to observe the effects of from the action made in the context in which they occur and to reflect. 


\section{Importance of the Study}

Students with low achievement can be improved by the use of concept maps in teaching and learning of economy subjects.

a) Assist the economics teacher in the school to make the concept map method as a form of teaching that is attractive for STPM level Economics student.

b) Assist the Economic committee at school and the state committee in an effort to improve the performance of economy subjects at STPM level.

c) The Curriculum Development Centre should develop teaching modules that use concept maps to enable the teachers to apply this technique at school.

The use of concept maps in computer based learning can help improve student achievement. This occurs because the concept maps are effective in training creative thinking and a new way of solving the problem (Buzan, 2004).

The concept map is also used as a teaching tool that can be combined with a variety of media (multimedia) to build students' understanding. The concept map can be seen as a new teaching aid to improve old learning method to encourage critical thinking. In addition, the concept map is also used to enhance students' learning experiences in order to create an effective learning environment (Canas et al., 2003).

According to Zain (2002), computer based learning can produce a smart learning environment that encourages students to think critically and creatively. This learning method stimulate student learning using a variety of intelligence to enhance the process of generating concept (Zain, 2002). Mind Map "or concept map is a tool to help you think and learn. The concept map was developed by Tony Buzan and is an effective method to making notes and useful to generate ideas with relevance.

According to Novak (1990), all the talent and potential of the brain can be developed through the comprehensive framework of brain and mind. If the structure and function of the brain operates in parallel with the students' emotions, brain based learning is able to produce a meaningful learning process to the students. Activities that require students to use ICT to create a character and write a good essay are suitable for both the use of the mind or the left brain for creativity and the right brain to practicality.

According to Moore et al. (2010) computer aided learning (computer aided teaching) is one of the successful approaches to revive the delivery of a teacher in the classroom. This shows that the use of computer aided learning in teaching and learning process fully using the computer has replaced the role of the teacher. An approach that uses computers for teaching and learning to learn a step by step of a planned program.

The use of course software and concept map can be concluded that the treatment learning with concept maps can provide a beneficial effect on increasing student achievement. This finding is consistent with the findings Aris (1999).

\section{Concept Map Software}

To construct a concept map, one should start in the middle page that become its main title. Then it sprout out in all directions producing a growing and organized structure containing keywords (keywords) and key figures (key images). An example of computer-based concept mapping is shown with the title "Basic Needs", 


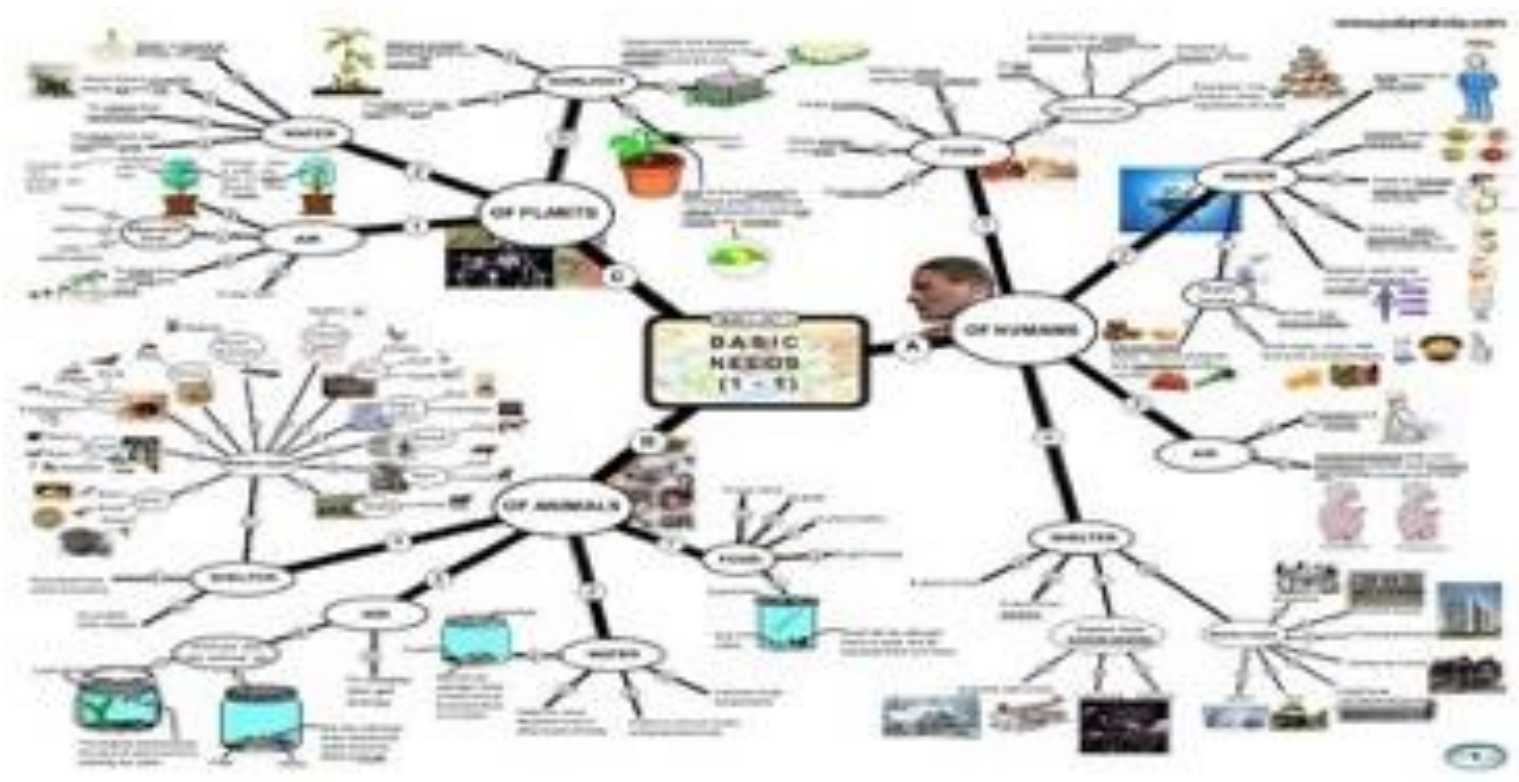

Figure 1. Basic Needs Computer-Based Concept Mapping

This software is derived from a program called Mind Mapper 'The rich virtual Tool For Brainstorming and Planning 2008 issued by SimTech Systems. Benefits of this program are able to understand a concept quickly, clearer communication, save time copying notes and the learning process will be more systematic and organized. Followed is the example of the use of concept maps using ICT. The specialty of this program is that students only need to make notes in Mind Manager software and the result can be converted to MS Words or MS Power Point by pressing the 'convert' under the icon that appears on the screen. Besides, students can produce creative notes by inserting videos, songs, animation and so on. This is one of the visual mind mapping programs that had existed over the years. This application has a lot of 48 capabilities which makes it easier to use and more attractive than traditional mind map. All the features that can be found in the application meets the tastes and needs of consumers in this era. Among the interesting features are:

- Support the creation of flow charts and mind maps.

- Allow visual diagram from user files to be included in the mind map.

- Choosing specific themes and subjects according to user requirements.

- Choosing to include colour, text, diagrams and so on according to user needs and requirements.

- Equipped with auto-focus application that allows users to keep the headlines in the middle of the screen and allows the user to change the appearance of other headlines more efficiently.

- Offer a more practical navigation map. 

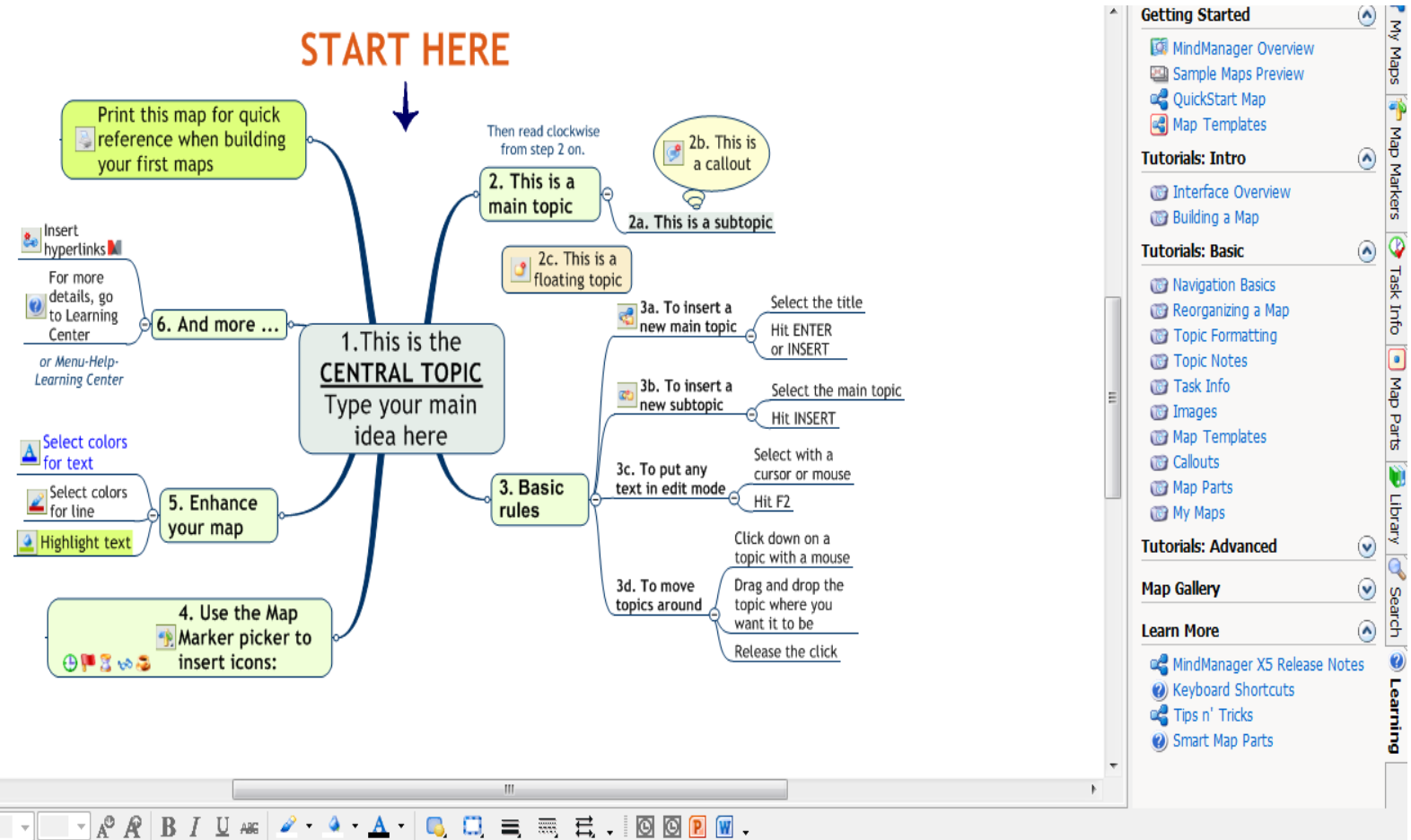

Figure 2. Central Topic Mapping

\section{Research Methodology}

\section{Study Design}

The design of this study is action research exploring the use of ICT based concept maps to improve knowledge recollection and the interest of students to make notes of facts and concepts in economic subjects. Kemmis and McTaggart Models (1988) 'action research cycle' is a model commonly used in conducting the action research. There are 4 key elements in this model which consist of reflect, planning, action and observe.

Step 1: Teachers will submit the title of the lesson learned by using concept maps and make explanations. All students have a mind map software on their computer and have followed the class how to use the software for 2 hours.

Step 2: Teachers in general introduce teaching materials and the main ideas of the topics to be taught. Teachers teach using a mind map.

Step 3: The students are asked to complete a mind map on an individual basis according to topics that have been taught by the teacher. The teacher gives guidance and monitor the students during producing ICT based concept map.

Step 4: Students present a concept map produced by the students and the teacher evaluates.

Step 5: Teacher distribute questionnaires related to the use of mind maps in learning by students.

Figure 3. Implementation Process of Teaching and Learning Economics Using ICT based concept map 


\section{Research Respondents}

Research respondents consisted of 10 students and a respondent selected with cause. According to Hanim (2004), action research did not use the word population due to action research does not require a generalized random sample of the population. 10 selected students consists of students taking basic economic subjects at STPM. Researchers were involved as the sample in this research process. This action research was conducted at the of School Tunku Ampuan Durah, Seremban for 8 hours a week with a teaching session of within 80 minutes of a meeting. The purpose of this study is to see the student acceptance of learning techniques and making notes using ICT based concept map. Students are taught titles that use a lot of concepts in Microeconomics subjects at STPM level such as supply and demand titles. In addition, this study aims to identify the attitude and perception of students' towards ICT based concept mapping technique in the process of teaching and learning.

\section{Research Instruments}

Measuring instrument contains a series of items which can give the impression of evaluation and interpretation of the figures obtained by producing meaning. The instrument used to obtain the research data was a questionnaire before (pre-test) and a questionnaire after (post test) and interviews.

Questionnaire 1: The response of students to remember methods and facts in a linear concept.

Questionnaire 2: The response of students towards ICT based concept mapping method for remembering concepts and facts.

Questionnaire 3: The response of students towards ICT based concept mapping method in remembering facts and concepts and make notes.

Response Analysis and Interpretation of data interviews ICT based concept mapping methods in making notes to remember concepts and facts rather than as a linear form.

\section{Procedures for Data Analysis}

Having carried out the data collection process, instruments and data collected samples were analyzed using Statistical Package for the Social Sciences (SPSS-PC for Window version 21.0). These data are analyzed using descriptive statistics to describe the mean and the percentage method of making and copying notes linearly, ICT based concept mapping methods to remembering concepts and facts, student responses to ICT based concept mapping methods in remembering facts and concepts in addition on making notes and ICT based concept mapping methods on making notes to remember concepts and facts rather than as a linear form.

\section{Research Findings \\ Respondents Profile}

Results of the analysis shows the distribution of 6 boys equivalent to $60 \%$ and the distribution of 3 female students which were equivalent to $30 \%$. Respondents age group is 18 years in which all respondents were from lower form six students. Out of 10 students, $30 \%$ have the computer skills in using MS Words, Excel and MS Power Point and the rest have only a basic level of computer skills in MS Words only. 10 of these students were also found to have poor levels of achievement based on their monthly test scores (mean score were 15) 


\section{Result Loop 1:}

Stage 1: Identifying the problem

Result from the questionnaire 1 showed that one of the factors that is causing difficulty for students to master the economic paper in STPM were not being able to remember concepts and facts learned. Students also found it difficult to remember concepts and facts in a planned and systematic way. In addition, students were also found writing notes unsystematically and are still making notes using the linear form method and do not use other methods such as using concept maps.

\section{Table 1}

Analysis of Questionnaire 1: The methods of making and copying notes linearly

\begin{tabular}{|c|c|c|c|c|c|}
\hline No & Statement & Agree & $(\%)$ & $\begin{array}{l}\text { Disagree } \\
\text { (students) }\end{array}$ & $(\%)$ \\
\hline 1. & $\begin{array}{l}\text { Copying linear notes to help me } \\
\text { remember what is taught by } \\
\text { teachers. }\end{array}$ & 3 & 30 & 7 & 70 \\
\hline 2. & $\begin{array}{l}\text { Copying linear notes help me recall } \\
\text { back easily of what were taught by } \\
\text { the teachers. }\end{array}$ & 2 & 20 & 8 & 80 \\
\hline 3. & $\begin{array}{l}\text { Copying notes linearly can help me } \\
\text { learn the Economy subject. }\end{array}$ & 4 & 40 & 6 & 60 \\
\hline 4. & $\begin{array}{l}\text { I can remember back to what was } \\
\text { taught by a teacher more easily if I } \\
\text { copy the notes linearly. }\end{array}$ & 3 & 30 & 7 & 70 \\
\hline 5. & $\begin{array}{l}\text { Copying notes linearly made me like } \\
\text { the subject of Economy. }\end{array}$ & 3 & 30 & 7 & 70 \\
\hline 6. & $\begin{array}{l}\text { Copying notes linearly helped me } \\
\text { make revisions easily. }\end{array}$ & 3 & 30 & 7 & 70 \\
\hline 7. & $\begin{array}{l}\text { Copying notes linearly is the best } \\
\text { way to learn Economics. }\end{array}$ & 3 & 30 & 7 & 70 \\
\hline 8. & I like to copying linearly notes. & 4 & 60 & 6 & 40 \\
\hline
\end{tabular}

In general, survey findings show that most students do not agree that the use of notes in linear form could help them remember the concepts and economic fact any easier. An average of $70 \%$ of respondents felt that they did not like copying notes in linear form and believe that the linear form of notes could not help them remember facts and concepts of economics easily.

Stage 2: Planning

Teachers plan on the title to be taught which were the title on demand. Teachers provide notes in the form of concept maps using ICT and explain to the students the learning content by using the concept map software.

Stages 3 and 4: Action and Reflection

For individual activities, students are assigned to complete the notes using concept maps based on ICT according to their own creativity. Once the teacher had presented the basic concepts of the title in the subject matter, the students assign their own assignments in which the students complete the tasks related to the concepts and facts that they had learned. The 
students used their own creativity such as using a pictures, colours, letters and so on to make it easier for them to remember the concepts and facts.

Students who have completed the assignment will present the results of their work. From the result of these activities, the teacher made random tests to test the students in remembering the concepts and facts that had been learned. Teachers also distribute questionnaire 2 to discover the response of students on the use of concept maps in teaching and learning in the classroom.

Based on the analysis of questionnaire 2, the use of ICT based concept map had raised students' positive feelings toward learning subject of economy. This can be proven and the findings of the questionnaire in which more than $60 \%$ of the students believe that the use of ICT based concept maps can help them learn and remember economy facts and concepts more easily and organized, while another $40 \%$ still agreed that making notes using the linear form is still simple and easier to use in addition that using a computer software takes time to master.

\section{Table 2}

Analysis of Questionnaire 2: Methods of ICT based concept maps to recall concepts and facts

\begin{tabular}{|c|c|c|c|c|c|}
\hline No & Statement & Agree & $(\%)$ & Disagree & $(\%)$ \\
\hline 1. & $\begin{array}{l}\text { Concept maps can help me } \\
\text { remember what were being taught } \\
\text { by the teacher. }\end{array}$ & 6 & 60 & 4 & 40 \\
\hline 2. & $\begin{array}{l}\text { Concept maps can help me easily } \\
\text { recall what were being taught by } \\
\text { the teacher }\end{array}$ & 6 & 60 & 4 & 40 \\
\hline 3. & $\begin{array}{l}\text { Concept maps can help me learn } \\
\text { Economics }\end{array}$ & 6 & 60 & 4 & 40 \\
\hline 4. & $\begin{array}{l}\text { I can recall back what was being } \\
\text { taught by the teacher with more } \\
\text { ease if I use concept maps to make } \\
\text { notes. }\end{array}$ & 7 & 70 & 3 & 30 \\
\hline 5. & $\begin{array}{l}\text { Concept maps made me like } \\
\text { economics. }\end{array}$ & 6 & 60 & 4 & 40 \\
\hline 6. & $\begin{array}{l}\text { Concept maps help me made } \\
\text { revisions easily. }\end{array}$ & 6 & 60 & 4 & 40 \\
\hline 7. & $\begin{array}{l}\text { The concept map is the best way } \\
\text { learn economics }\end{array}$ & 6 & 60 & 4 & 40 \\
\hline 8. & $\begin{array}{l}\text { I like to copying notes using concept } \\
\text { maps }\end{array}$ & 6 & 60 & 4 & 40 \\
\hline
\end{tabular}

In post test 2 an average $40 \%$ of the students still do not approve the use of concept maps can improve remembering economic concepts and facts while an average $60 \%$ of the students began to approve the use of concept maps can improve remembering economic concepts and facts. Researchers assume $40 \%$ of the students are still not familiar in using this software and a few were less skilled in using computers. Researchers continued with the teaching and learning process on the economic title of offering. The weak group who mainly those unskilled 
on using computers were taught and given additional training on the use this software for 2 period ( 80 minutes) outside normal teaching hours in order to become more proficient.

\section{Result Loop 2}

Stage 2, 3 and 4: Planning, Action and Reflection

The teachers had planned that for the next teaching session, they will explain more about the economic terminology and use the appropriate terms to the level of student thinking. Researcher (teacher) used very concise concept maps in the presentation of the topic. Researchers show examples of concepts maps with a variety of creativity with the intention that students will be interested in making a systematic and structured notes.

For teachers' individual activities, students are assigned to complete their notes using ICT concept maps according to their own creativity. Once the teacher present the basic concepts of the title in the subject matter, the students will then make their own assignments in which the students complete tasks related to the concepts and facts that have been learned. Students then use their creativity such as inserting pictures, colours, letters and so on to ease them to recall the concepts and facts. Students will also be given time of two period to complete the whole note on the title of supply and demand.

Upon completion of the assignments for two days, each student is required to present their work and in which the teacher will provide grades. They had also distributed a written question related to the concept and fact on both titles that had been taught. Teachers also had distributed questionnaires such as the questionnaire 3.

\section{Table 3}

Analysis of Questionnaire 3: Method of ICT based concept maps in making notes to recall concepts and facts

\begin{tabular}{|c|c|c|c|c|c|}
\hline No & Statement & $\begin{array}{l}\text { Agree } \\
\text { (student) }\end{array}$ & $(\%)$ & $\begin{array}{l}\text { Disagree } \\
\text { (student) }\end{array}$ & (\%) \\
\hline 1. & $\begin{array}{l}\text { Concept maps can help me recall } \\
\text { what was being taught by the } \\
\text { teacher. }\end{array}$ & 8 & 80 & 2 & 20 \\
\hline 2. & $\begin{array}{l}\text { Concept maps can help me think } \\
\text { back with easily what is taught by } \\
\text { teacher. }\end{array}$ & 8 & 80 & 2 & 20 \\
\hline 3. & $\begin{array}{l}\text { Concept maps can help me learn } \\
\text { Economics. }\end{array}$ & 8 & 80 & 2 & 20 \\
\hline 4. & $\begin{array}{l}\text { I can recall back what was being } \\
\text { taught by the teacher more easily if } \\
\text { I use concept maps to make notes. }\end{array}$ & 8 & 80 & 2 & 20 \\
\hline 5. & $\begin{array}{l}\text { Concept maps made me like } \\
\text { economics. }\end{array}$ & 8 & 80 & 2 & 20 \\
\hline 6. & $\begin{array}{l}\text { Concept maps help me make } \\
\text { revisions easily. }\end{array}$ & 8 & 80 & 2 & 20 \\
\hline 7. & $\begin{array}{l}\text { The concept map is the best way } \\
\text { learn economics. }\end{array}$ & 8 & 80 & 2 & 20 \\
\hline 8. & $\begin{array}{l}\text { I like to copy notes using concept } \\
\text { maps. }\end{array}$ & 8 & 80 & 2 & 20 \\
\hline
\end{tabular}


Based on the analysis of questionnaires 3, the use of ICT based concept map has raised students' positive feelings toward learning economy. It can be proven and the findings of the questionnaires in which more than $80 \%$ of the students believe that the use of ICT based concept maps can help them learn and recall facts and economic concepts more easily and organized while $20 \%$ still agreed that making notes using the linear form are still simple and easy to use in addition computer software takes time to master. Also, in addition to questionnaires, the researcher also interviewed the 10 respondents and the results are as follows:

\section{Table 4}

Response analysis and data interpretation interview 4: ICT based concept mapping method in making a note to recall concepts and facts than in linear form

\begin{tabular}{|c|c|c|c|c|c|}
\hline $\begin{array}{l}\text { Questions } \\
\text { /respondent }\end{array}$ & $\begin{array}{lr}\text { Copying } & \text { notes } \\
\text { using ICT } & \text { based } \\
\text { concept mapping } \\
\text { difficult } \\
\text { enjoyable }\end{array}$ & $\begin{array}{lr}\text { Making notes } \\
\text { based on ICT } \\
\text { concept maps } \\
\text { have } \\
\text { easier been } \\
\text { difficult }\end{array}$ & $\begin{array}{l}\text { Making notes } \\
\text { using concepts } \\
\text { map can help } \\
\text { recall concepts } \\
\text { and facts quickly }\end{array}$ & $\begin{array}{l}\text { Making notes } \\
\text { using concept } \\
\text { maps eases } \\
\text { revision }\end{array}$ & $\begin{array}{l}\text { Like it or not if } \\
\text { teacher use ICT } \\
\text { based concept } \\
\text { maps in teaching } \\
\text { / giving notes }\end{array}$ \\
\hline 1. & Enjoyable & Easier & Yes & Yes & Like \\
\hline 2. & Enjoyable & Easier & Yes & Yes & Like \\
\hline 3. & Enjoyable & Easier & Yes & Yes & Like \\
\hline 4. & Enjoyable & Easier & Yes & Yes & Like \\
\hline 5. & Enjoyable & Easier & Yes & Yes & Like \\
\hline 6. & Enjoyable & Easier & Yes & Yes & Like \\
\hline 7. & Enjoyable & Easier & Yes & Yes & Like \\
\hline 8. & Difficult & Difficult & No & No & Dislike \\
\hline 9. & Enjoyable & Easier & Yes & Yes & Like \\
\hline 10 & Difficult & Difficult & No & No & Dislike \\
\hline
\end{tabular}

From the feedback of 8 students (80\%) indicated, the use of ICT based concept maps prove to be fun during copying notes, makes it easier to make notes, can help you remember the concepts and facts, as well as a making revision easier like if teachers use this method during the process of teaching and learning in class. The use of ICT based concept maps allows the students to recall concepts and facts quickly and orderly as well as to ease revision activities. Students also prefer if the teacher teaches and gives notes in the form of ICT based concept maps because the students can modify and add notes given by inserting picture element, colour, animation and even numbers in the sequence of facts or concepts. Out of the 10 students who disclosed this method, 2 (20\%) students showed a negative feedback because researchers found that that the 2 students were not skilled in the use of ICT in addition of having no ICT facilities at home and feel that notes made using this method is too brief.

\section{Discussion}

The result of this study showed that the use of ICT based concept maps have shown a positive effect and could improve the interest of students to recall and make notes for revision. Students can list concepts and facts related to the topic of demand in a structured and 
organized manner. The use of pictures or images and numbers can be modified had been shown to stimulate the brain to produce more ideas and information better. This finding is supported by the studies by Paivio (1971). The result of this study generally showed no significant differences in the mastery of concepts and facts before and after the use of ICT based concept maps. In order to increase the students' interest in the subject of economics which was considered as a boring and difficult subject (Hussin, 1999), cognitive strategies can be used to teach them.

Teaching methods using special software which use concepts map for the title of demand should be used by teachers teaching economy. The use of this method should be given attention so that the students' perception of this topic which was considered difficult can be changed into something simpler. This method helps the students to organize on a regular basis the concepts in their minds to enable them to understand and remember the concepts. Students and teachers also need to be exposed to the methods of constructing and using concept maps extensively in the teaching and learning process. This exposure were intended to boost the student mastery of difficult topics and topics which had many interrelated concepts. Various seminars and workshops can be conducted at schools and departments to provide an understanding of the construction and use of concept maps. In addition, the Ministry of Education can also benefit from this study through emphasis and encourage the use of electronic media for teachers in teaching. Teachers should also be given more training on how to teach through the use of electronic media. The effort to produce instructional software by concept maps should be intensified particularly if the topic is difficult because so far there are only a few title which were provided the teaching software and this is not enough.

\section{Conclusion}

Teachers should not make a narrow perception on the assumption that concept maps is only intended to teach the students but also should use it as a teaching method in the classroom. If used correctly it can help students' learn concepts nicely and effectively. School committee meetings, whether district and state is an important activity conducted at school or the education department as a place for discussions to improve the teaching method in the classroom. Teachers do not have a negative perception of the latest findings in this teaching technique because as teachers they must find the best method or technique to be used in the classroom.

This study is important to the various parties associated with the direction of education in realizing the objectives of the national education. This is because it is they who will determine whether the process could effectively be completed. Various problems can be identified, and thus the party will take the initiative so that the implementation of this practice could be continued on successfully. School Inspectorate, Teacher Education Division, EPRD, Department of Education, Principals and others are the responsible party in this case and can do something relevant.

\section{Acknowledgements}

The researchers would like to convey our appreciation to the Eduactional State Department of Negeri Sembilan and Educational State District Office of Seremban for their valuable support in carrying out this study. 


\section{References}

Aris, S. R. S. (1999). Keberkesanan penggunaan peta konsep dalam pembelajaran konsep mol di kalangan pelajar kejuruteraan elektrik di Institut Teknologi Mara. (Unpublished thesis). Universiti Malaya, Kuala Lumpur.

Buzan, T. (2004). Mind maps for kid. London: Thorsons.

Canas, A. J., Coffey, J. W., Carnot, M. J., Feltovich, P., Hoffman, R. R., Feltovich, J. \& Novak, J. D. (2003). A summary of literature pertaining to the use of concept mapping techniques and technologies for education and performance support. The Chief of Naval Education and Training Pensacola Fl 32500.

Carr, W., \& Kemmis, S. (1986). Becoming Critical: Education, knowledge and action research. London: Falmer.

Hanim, Z. 2004. Penggunaan pembelajaran koperatif dalam Matematik. Penyelidikan tindakan di sekolah rendah di Kalimantan Timur, Indonesia. (Unpublished doctoral dissertation). Fakulti Pendidikan, Universiti Kebangsaan Malaysia.

Hussin, M. (1999). The Contribution of Instruction in a Knowledge Mapping Technique to

Students' Understanding of Economics Texts. (Unpublished doctoral dissertation). University of Wales Cardiff.

Kemmis, S., \& McTaggart, R. (1986). The Action Research Planner (3rd ed.). Geelong, Victoria: Deakin University Press.

Kemmis, S., \& McTaggart, R. (1988). The action research planner (3rd ed.). Geelong: Deakin University.

McNiff, J., Lomax, P., \& Whitehead, J. (2003). You and your action research project. London: RoutledgeFalmer.

Moore, D., McGrath, P. , \& Thorpe, J. (2010). Computer-Aided Learning for People with Autism - a Framework for Research and Development (pp. 218-228). Innovation in Education and Teaching International.

Novak, J.D. (1990). Concept mapping. A useful tool for science education. Journal of Research in Science Teaching, 27(10), 937-949.

Novak, J. D., \& Gowin, D. B. (1984). Learning How to Learn. Cambridge: Cambridge University Press.

Paivio, A. (1971). Imagery and Verbal Processes. New York: Holt, Rinehart and Winston.

Schaal, S. (2008). Concept mapping in science education assessment: An approach to computer - supported achievement tests in an interdisciplinary hypermedia learning environment. Germany: University of Education Ludwigsburg.

Steven, N. T. (2000). Using Concep Maps As Cooperative Learning Activities To Explore Hemodynmaic Principles. Southeast Missouri State University.

Tee, T. K., Yunos, J. Md., Mohamad, B., Othman, W., \& Yee. M. H. (2009). Kepentingan peta konsep Sebagai alat berfikir dalam mengambil nota kuliah. http:// eprinths. uthm.edu. my/609/1/ Jailani.

Yeyiloglu, S., Altun, Y., \& Koseoglu, F. (2008). Using concept maps to explore pre-service chemistry teachers conceptual understandings about scientific as a subject matter. Turki: Gazi University.

Zain, I. (2002). Elemen dalam multimedia ke arah penjanaan minda kritis dan kreatif. Seminar Penyelidikan Pendidikan, Institut Perguruan Darulaman, Kedah. 